\title{
Population Structure of a Remnant Quilombo Community: An Analysis of the Inbreeding and Ethnic Admixture
}

\author{
Juliana de Oliveira Cruz ${ }^{1,2^{*}}$, Patrícia Santos Pereira Lima1, Sandra Mara Bispo Sousa ${ }^{*}$ \\ ${ }^{1}$ Department of Natural Sciences, State University of Southwest Bahia, Vitória da Conquista, Bahia, Brazil \\ ${ }^{2}$ Graduate Program in Genetics, Institute of Biological Sciences, Federal University of Minas Gerais, Belo Horizonte, Brazil \\ Email: *juftoc@gmail.com, *sandra.mara@uesb.edu.br
}

How to cite this paper: Cruz, J.O., Lima, P.S.P. and Sousa, S.M.B. (2020) Population Structure of a Remnant Quilombo Community: An Analysis of the Inbreeding and Ethnic Admixture. Open Access Library Journal, 7: e6207.

https://doi.org/10.4236/oalib.1106207

Received: March 4, 2020

Accepted: April 7, 2020

Published: April 10, 2020

Copyright () 2020 by author(s) and Open Access Library Inc.

This work is licensed under the Creative Commons Attribution International License (CC BY 4.0).

http://creativecommons.org/licenses/by/4.0/

\begin{abstract}
The histories and oral traditions identify rural communities them as quilombos and that are currently denominated quilombo remnants in Brazil. The formation of these communities was usually carried out by a small number of individuals who remained isolated for generations. This study is an analysis of the effects of inbreeding and ethnic admixture in the remaining quilombo community Tucum in the South-Center region of the State of Bahia, in Brazil. The inbreeding values were obtained through inbreeding coefficients and genealogical database. The admixture analysis was conducted by phenotypic and cultural index. Other demographic genetic parameters were evaluated in the search for the better understanding of the population structure. A total of 489 individuals were analyzed for effective population size $\left(N_{e f}\right)$, inbreeding coefficient expected $(\varnothing)$, inbreeding coefficient $(F)$ and mean inbreeding coefficient $(F)$ resulting in $384,0,0.144,0.0086$, respectively. The community presents $20.64 \%$ of consanguineous marriages and an inbreeding coefficient $(r)$ of 0.288 . These data are larger than those found in the total Brazilian population and to other traditional communities analyzed in the country. The admixture analysis revealed a Negroid Phenotypic Index (NPI) of 0.60 and the Negroid Cultural Index (NCI) of 0.33 , lower than that found in other remnants. The isolation index $(i)$ helps to understand this pattern of population structure, and the community studied was not a genetic isolate $(i=22.4)$ demonstrating a large migratory flow. Based on the data presented, it is possible to conclude that the community is not a genetic isolate, transcending the initial implications of the founding effect. However, the high migration does not prevent inbreeding and high rates of consanguineous marriages, influenced by cultural ethnic characters, which may change evolutionary mechanisms, as genetic drift, alleles fixation, natural selection (for preferential selection) and an increase in genetic diseases.
\end{abstract}




\section{Subject Areas}

Genetics

\section{Keywords}

Ancestry, Anthropogenetics, Black Population, Inbreeding

\section{Introduction}

In the beginning of the slave trade to Brazil from 1551 to 1870 , an estimative of four million Africans were brought to work in the agriculture and ore. It is known the importance of anthropological, historical, linguistic and social impact of this colonization process that occurred in the country. Together with the Europeans and Amerindians, the Africans represent the basis of formation of the Brazilian people [1] [2] [3] [4] [5].

Slaves who did not accept the submissions and forced labor would revolt. Fugitives took refuge in places of difficult access, forming rural communities whose histories and oral traditions identify them as Quilombos and that are currently denominated quilombo remnants in Brazil [6]. The formation of these communities was usually carried out by a small number of individuals who remained isolated for generations [7].

Historically thinking about the process of enslavement and liberation of the black people in Brazil raises a current debate that encompasses the inequalities that characterized and still characterize the search for citizenship by those peoples who are marked by exclusion. Most of the Brazilian population is made up of blacks or mixed race, and a large proportion of these are found in the poorest spheres of the population. This extends to quilombola communities, as a historical consequence of inequities to which blacks have been subjected and are subjected, including in relation to health care and education [8] [9].

Aiming to correct this debt with the black population, especially with the quilombolas the Brazilian government, through decrees seeks to regularize of identification procedures, delimitation, demarcation and titling of lands occupied by the remnants of quilombola communities. In addition to a series of actions to ensure access to land, infrastructure and quality of life, productive inclusion and citizenship rights. So, once certified, these communities receive greater attention from the state, and this is expected to reflect better living and health conditions [10] [11].

Traditional communities are of great interest in population genetic studies due to the founder effect and genetic isolation, which leads the population to a process of micro differentiation, mainly due to genetic drift [12] [13]. Genetic investigations of the Brazilian population show that this ethnic admixture of a trihybrid population composed by Africans, Europeans and Amerindians can be analyzed by phenotypic and cultural markers such as skin color, physiognomy and surname analysis [14] [15] [16] [17] [18]. 
For the better characterization in population studies, only biological evaluations are not enough, being extremely important to know the history of the population and to seek to converge biological, historical and cultural in the investigation of genetic identity [19]. This integrated approach enables the better understanding of factors that act in the microevolutionary processes, as the founder effect and genetic drift.

Given the biological and cultural implications of the colonization of the country and the formation profile of traditional communities, this study analyzed the effects of inbreeding and ethnic admixture in the remnant quilombo community Tucum, in the Center-South of the state of Bahia by using demographic genetic data.

\section{Methods}

\subsection{Collection and Characterization of the Samples}

The present study was carried in the remnant community of Quilombo Tucum, located in the city of Tanhaçu part of the Central-South macro-region in Bahia. The community was founded in 1800 by three individuals and recognized in 2006 by the Palmares Cultural Foundation (PCF). This study was approved by the Ethics and Research Committee of the State University of Southwest Bahia (Universidade Estadual do Sudoeste da Bahia-UESB) under the number:

41728314.8.0000.0055. The informed consent form was signed by all participants. Demographic genetic data were obtained through a questionnaire applied from June to August 2015.

\subsection{Data Analysis}

The data collected from 157 families were used in the calculation of: effective population size $\left(N_{e f}=1 / 2\left\{1-[1-F(t)]^{1 / t}\right\}\right)$ [20], reproductive population $\left(N_{r}\right)$, mean number of children

$$
k=\frac{\text { Total children }}{\mathrm{N}^{\circ} \text { families with children up to } 30 \text { years }},
$$

consanguineous marriages, inbreeding coefficient expected

$$
\varnothing=\frac{\left(1-M e^{2}\right)}{\left[2 N e-(2 N e-1) \cdot(1-M e)^{2}\right]} \quad[21],
$$

mean inbreeding coefficient $(F)$, coefficient of consanguinity $r=\sum(1 / 2)^{n}$, inbreeding coefficient $F=r / 2$ [1] [21], effective migration

$$
M e=\sqrt{M(M+2 K)},
$$

where $M$ is born at a distance $\leq 142.8 \mathrm{~km}$ and $K$ is born at a distance $\geq 7.66 \mathrm{~km}$ and isolation index $(i=\mathrm{Ne} \cdot \mathrm{Me})[22]$.

The Negroid phenotypic index (NPI) was obtained by the quotient of the sum of the individuals classified as medium mixed race, dark mixed race and black by the total of individuals in the sample who were classified. The Negroid cultural index (NCI) was calculated by the frequency of surnames of religious connotation found in the study population [23]. To eliminate underestimation bias, the analyses were only conducted on individuals with complete pedigree. 


\section{Results}

The quilombola community Tucum nowadays has a different profile from the time of its foundation in 1800 . This refers to the population size and ethnic names of the people who populate today. With the recognition by the PCF, farms located around the foundation center were encompassed the Tucum community. It currently has a population of approximately 670 inhabitants, with about 200 families distributed in sub communities: Lança, Fazenda Velha, Jenipapo, Gentil, Boa Esperança, Batateira, Lagoa do Capim, Lagoa da Pedra, Tapagem and Tucum.

Of the 200 families in the community, 157 agreed to participate in the study, resulting in a population size of 489 , with an average number of 5 children per family. All these families have a registry at the Family Health Unit, where they are followed up in terms of common diseases such as: hypertension, heart disease, diabetes and other diseases. More than $75 \%$ of the population is not affected by hypertension, diabetes and heart disease. The abortion rate is $7.16 \%$, while stillbirth is $0.98 \%$. Infant and child mortality reached $5.75 \%$ and $1.24 \%$ of the population, respectively.

Based on the data collected, the following genetic and cultural parameters were estimated, results in: $N_{e f}=384, N_{r}=278$. The community presented $20.64 \%$ of consanguineous marriages. The consanguinity and inbreeding analyze result in: $\varnothing=0, r=0.288, F=0.144, \bar{F}=0.0086$; $M e$ was 45.81 with an isolation in$\operatorname{dex}(i)$ of 22.2. The cultural phenotypic data resulted in an NPI $=0.60, \mathrm{NCI}=$ 0.33 .

The genetic diseases present in the community are: a) autosomal recessive inheritance pattern, such as sickle-cell anemia and Situs InversusTotales, both of which were originated from consanguineous marriages between second cousins and with a frequency in the population of $0.0020 \%$ (Figure 1 and Figure 2); b) autosomal dominant inheritance pattern such as polydactyly and syndactyly, with a frequency in the population of $0.0020 \%$ e $0.0040 \%$ respectively (Figure 3 ).

All individuals of Figure 1 resided or reside in the Tucum subcommunity, with three individuals identified as heterozygous and one homozygous for sickle cell anemia. The allelic frequency was not calculated in the community due to the absence of molecular data. All individuals of Figure 2 resided or reside in the Tapagem subcommunity, with one affected individual, and all individuals of Figure 3 resided or reside in the Tucum subcommunity, with two affected individuals.

\section{Discussion}

Quilombola communities in Bahia are widely studied due to the great cultural diversity and formation that is found in different regions of the State. Descriptions that encompass population and demographic genetics are initial points for the knowledge of the profile of these communities. Anthropological and demographic 


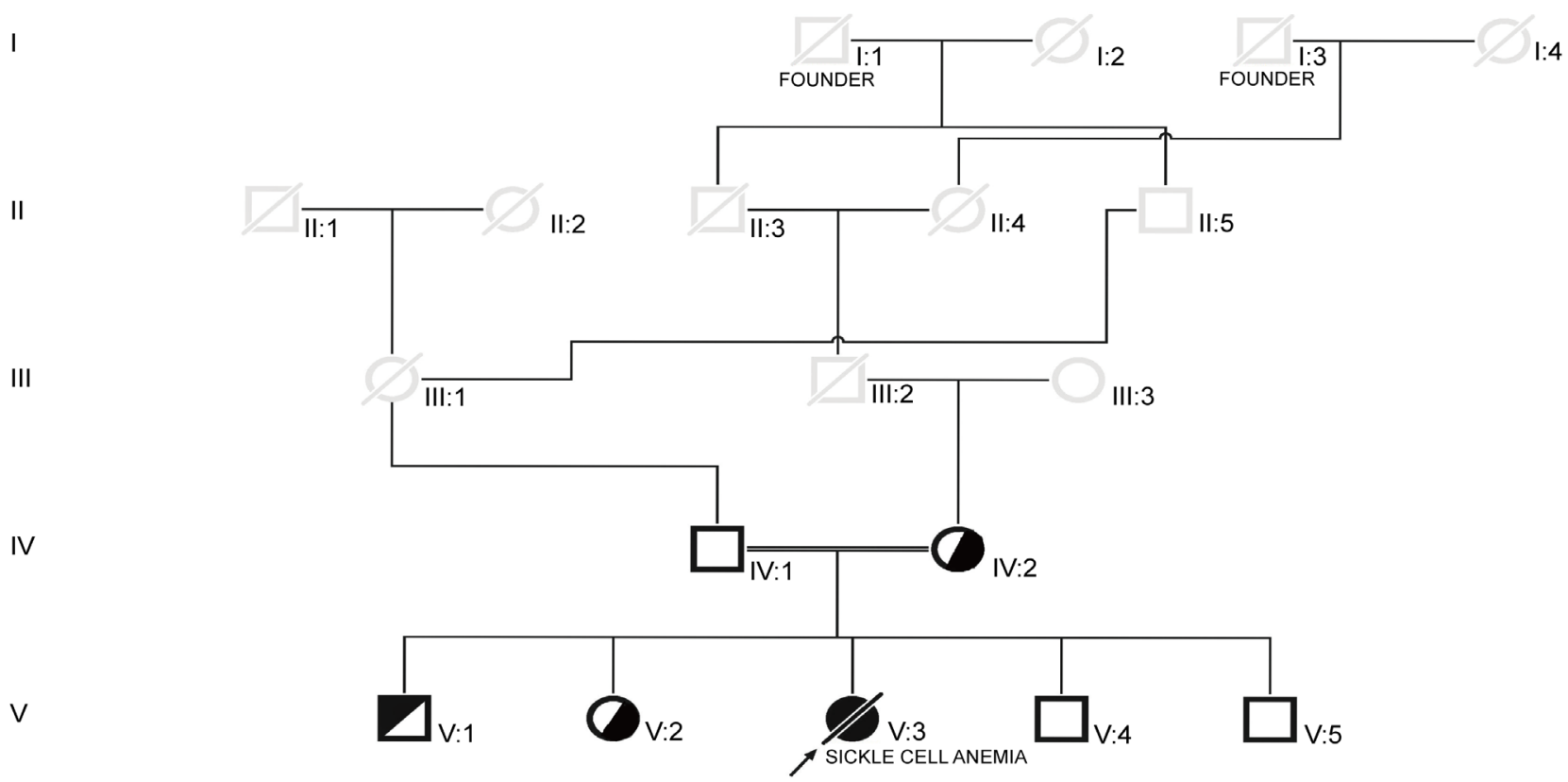

Figure 1. Heredogram with occurrence of Sickle Cell Anemia, individual V: 3.

I

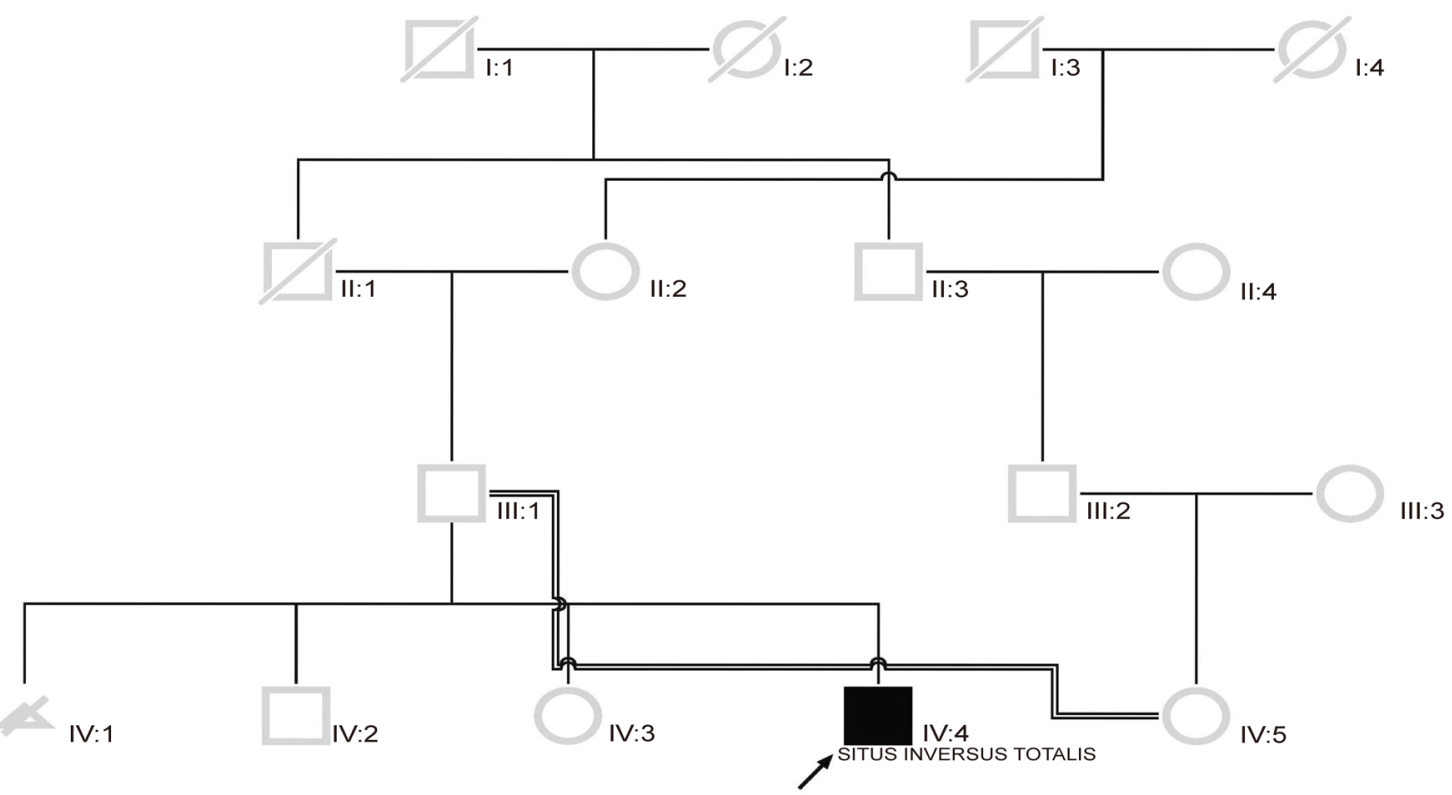

Figure 2. Heredogram with occurrence of Situs inversus Totalis, individual IV: 4.

studies of native populations in Brazil show that some communities, despite fluctuations in birth rates and mortality, show a growth [24]. This is seen in the community, which in addition to having a large number of families, there is a high average number of children per family and a rate of abortion, stillbirth, infant and child mortality lower than the Brazilian and Northeastern region [25]-[27]. In relation to the complex diseases that affect the Brazilian population, the community is below the national rate, even in relation to hypertension. The hypertension has a prevalence of $25 \%$ in the Brazilian population; this prevalence tends to increase with increasing age, low schooling, female sex and African ethnicity [28]. 


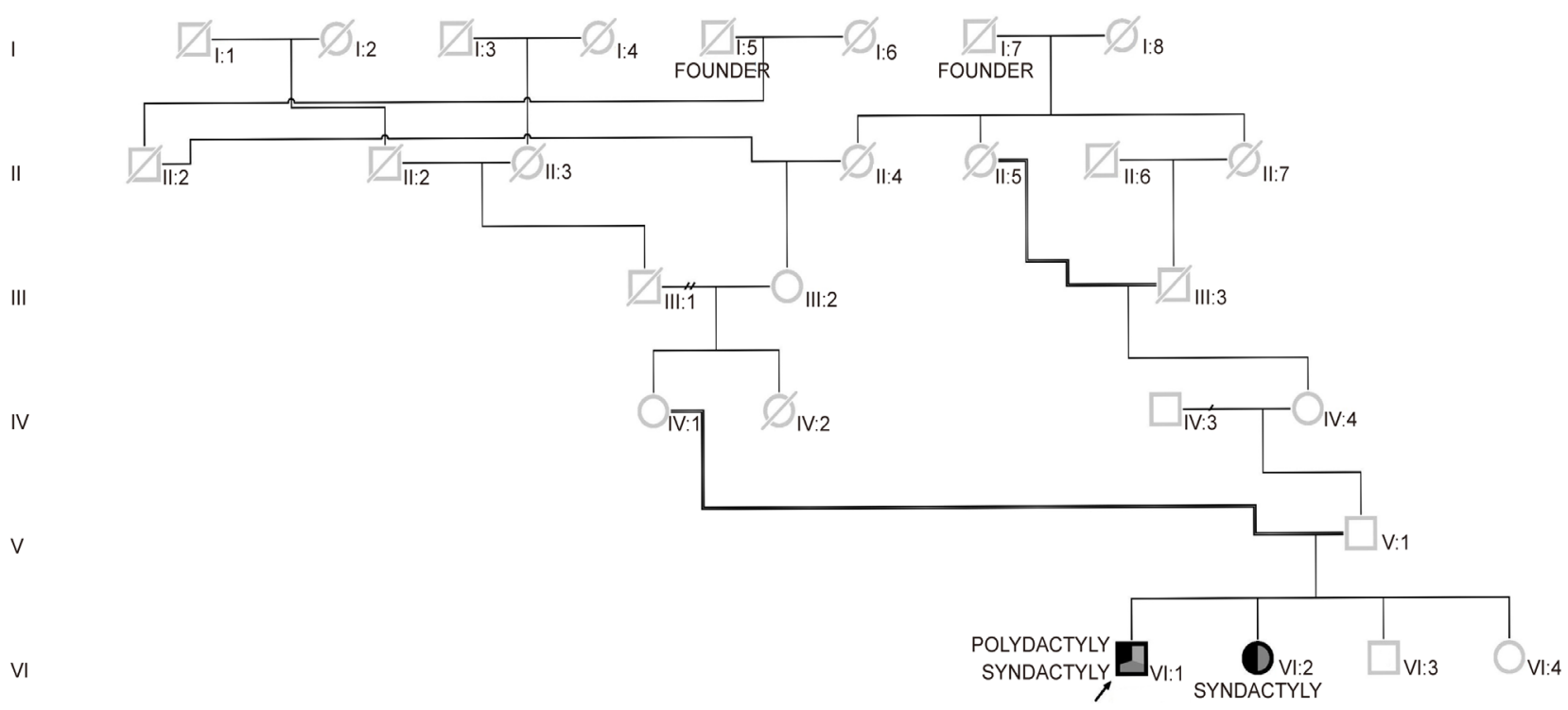

Figure 3. Heredogram with occurrence of Polydactyly and Syndactyly, individual VI: 1 and Syndactyly, individual VI: 2.

The community in its founding had a small number of three couples. During the process of community formation, for various reasons, Indians and slaves maintained friendly relations starting the admixture process between the ethnic groups and increasing the number of community members. With the improvement of access to means of transportation and communication, $M e$ receives an increase, breaking down, the levels of isolation of the community.

A higher $M e$ negatively influencing parameters such as IFN, ICN and $i$, since individuals from different backgrounds with phenotypic characteristics and surnames of different connotations end up entering in the community, leading to bias in the analysis. The IFN (0.60) and the ICN (0.33) are low when compared to other Bahian remnants [29] [30], demonstrating a high miscegenation of the population. The admixture which is seen can also be due to the land demarcation process by the responsible agencies (PCF), where all the lands near the central point of foundation, are now recognized as remnant quilombo.

Populations with an $i<5$, not isolated, provide a scenario of low inbreeding. However, this is not seen in the community, where the values of $F, \bar{F}$ and $r$ are higher than expected in large populations and values found in other traditional populations [13] [31]. Nevertheless, the community is of great importance in anthropogenic studies, considering the implications of inbreeding on the development of genetic diseases common in certain ethnic groups such as sickle cell anemia, hypertension and types of cancer such as prostate.

From the earliest days of society, inbreeding is preferred because of the social and economic security provided by the relationship [32]. However, in traditional communities, besides migratory movements and economic issues, cultural and ethnic affinity are determining factors for the development of matrimony and reproduction. This is the scenario that is visualized in the community, according to oral reports, from the beginning of its foundation. 
A non-random reproduction pattern increases the genetic correlation between individuals and may increase the incidence of autosomal recessive genetic diseases with and without ethnic correlation [33], such as sickle cell anemia and $\mathrm{Si}$ tus Inversus Totalis, respectively. In Brazil, sickle-cell anemia affects 0.1 to $0.3 \%$ of the black population, with a tendency to increase significantly due to the high degree of miscegenation found in the country [34] [35]. In Bahia the disease incidence is $1: 650$, while for the sickle cell trait is $1: 17$ for live births [36], the incidence in the community is below the national end regional level. Situs Inversus Totalis does not have an ethnic predisposition reported being present in $0.01 \%$ of the world population, being considered rare [37]. The association of consanguine marriages with late start complex diseases, such as diabetes, cardiovascular disease and cancer, still needs further studies that point to preexisting risks [38] [39].

\section{Conclusion}

Based on the data presented, it is possible to conclude that the community is not a genetic isolate, transcending the initial implications of the founder effect. However, high migration flow does not prevent inbreeding and high rates of consanguineous marriages, influenced by ethnic cultural characters, which can alter evolutionary mechanisms, such as genetic drift, allele fixation, natural selection (by preferential selection), and increase genetic diseases. This work is limited by the absence of molecular data, but these results open the way for new future studies with analysis of genetic polymorphisms and the role of ancestry in the incidence of diseases in this population.

\section{Acknowledgements}

We thank all individuals from the quilombola community Tucum for accepting to participate in the work and contribute to scientific development in the country.

\section{Conflicts of Interest}

The authors declare no conflicts of interest regarding the publication of this paper.

\section{References}

[1] Salzano, F.M. and Freire-Maia, N. (1967) Populações brasileiras: Aspéctos demográficos, genéticos e antropológicos. Companhia. São Paulo.

[2] Reis, J.J. (2000) Presença negra: Conflitos e encontros, in Instituto Brasileiro de Geografia Estatística (2000) Brasil: 500 Anos de Povoamento. IBGE, Rio de Janeiro, 80-99.

[3] Klein, H. (2002) As origens Africanas dos escravos brasileiros. In: Pena, S.D.J., Ed., Homo brasilis. Aspectos genéticos, linguísticos, históricos e socioantropológicos da formação do povo brasileiro, FUNPEC, Ribeirão Preto, 93-112.

[4] Bortolini, M.C., Thomas, M.G., Chikhi, L., Aguilar, J.A., Castro-De-Guerra, D., Salzano, F.M. and Ruiz-Linares, A. (2004) Ribeiro's Typology, Genomes and Spanish Colonialism, as Viewed from Gran Canaria and Colombia. Genetics and Molecular Biology, 27, 1-8. https://doi.org/10.1590/S1415-47572004000100001 
[5] Pereira, F.S.C.F., Guimarães, R.M., Lucidi, A.R., Brum, D.G., Paiva, C.L.A. and Alvarenga, R.M.P. (2019) A Systematic Literature Review on the European, African and Amerindian Genetic Ancestry Components on Brazilian Health Outcomes. Scientific Reports, 9, 8874. https://doi.org/10.1038/s41598-019-45081-7

[6] Anjos, R.S. and Cipriano, A. (2007) As comunidades no território nacional. In: Quilombolas. Tradições e cultura da resistência, Aori Comunicação, São Paulo, 176-206.

[7] Schmitt, A., Turatti, M.C.M. and Carvalho, M.C.P. (2002) A atualização do conceito de quilombo: Identidade e território nas definições teóricas. Ambiente \& Sociedade, 10, 129-136. https://doi.org/10.1590/S1414-753X2002000100008

[8] Freitas, D.A., Caballero, A.D., Marques, A.S., Hernández, C.I.V. and Antunes, S.L.N.O. (2011) Saúde E Comunidades Quilombolas: Uma revisão de literatura. Revista CEFAC, 13, 937-943. https://doi.org/10.1590/S1516-18462011005000033

[9] Pinto, A.R., Borges, J.C., Novo, M.P. and Pires, P.S. (2014) Quilombos Do Brasil: Segurança Alimentar E Nutricional Em Territórios Titulados. Cadernos de Estudos Desenvolvimento Social em Debate, 26, 4-66.

[10] Brasil (2003) Comunidades Quilombolas-Decreto $\mathrm{N}^{\circ}$ 4.901. Diário da União, 13.

[11] Brasil (2012) Programa Brasil Quilombola: Diagnóstico de Ações Realizadas, in Secretaria de Políticas de Promoção da Igualdade Racial, 291-331.

[12] Cavalli-Sforza, L.L. and Bodmer, W.F. (1971) The Genetics of Human Populations. W. H. Freeman, Dover Publications, San Francisco, CA.

[13] Lemes, R.B., Nunes, K., Meyer, D., Mingroni-Netto, R.C. and Otto, P.A. (2014) Estimation of Inbreeding and Substructure Levels in African-Derived Brazilian Quilombo Populations. Human Biology, 86, 276-288. https://doi.org/10.13110/humanbiology.86.4.0276

[14] Bortolini, M.C., Da Silva, W.A.J., De Guerra, D.C., Remonatto, G., Mirandola, R., Hutz, M.H., Weimer, T.A., Silva, M.C., Zago, M.A. and Salzano, F.M. (1999) African-Derived South American Populations: A History of Symmetrical and Asymmetrical Matings According to Sex Revealed by Bi- and Uni-Parental Genetic Markers. American Journal of Human Biology, 11, 551-563. https://doi.org/10.1002/(SICI)1520-6300(1999)11:4<551::AID-AJHB15>3.0.CO;2-Z

[15] Carvalho-silva, D.R., Santos, R., Rocha, J. and Pena, D.J. (2001) The Phylogeography of Brazilian Y-Chromosome Lineages. The American Journal of Human Genetics, 68, 281-286. https://doi.org/10.1086/316931

[16] Salzano, B.F.M. and Bortolini, M.C. (2001) The Evolution and Genetics of Latin American Populations. Cambridge University Press, Cambridge, 512. https://doi.org/10.1017/CBO9780511666100

[17] Guerreiro-Junior, V., Bisso-Machado, R., Marrero, A., Hünemeier, T., Salzano, F.M. and Bortolini, M.C. (2009) Genetic Signatures of Parental Contribution in Black and White Populations in Brazil. Genetics and Molecular Biology, 32, 1-11. https://doi.org/10.1590/S1415-47572009005000001

[18] Long, J.C. and Bortolini, M.C. (2011) New Developments in the Origins and Evolution of Native. American Journal of Physical Anthropology, 146, 491-494. https://doi.org/10.1002/ajpa.21620

[19] Azevêdo, E.S. (1982) Populações Da Bahia: Genética E História. Universitas, 29, 3-13.

[20] Templeton, A.R. (2006) Population Genetics and Microevolutionary Theory. Wiley-Liss, Washington DC, 720. https://doi.org/10.1002/0470047356

[21] Wright, S. (1943) Isolation by Distance. Genetics, 28, 114-138. https://doi.org/10.1093/nq/184.4.114g 
[22] Malecot, G. (1948) Les mathematiques de l'heredite. Masson \& Cie, Paris.

[23] Azevêdo, E.S., Fortuna, C.M., Silva, K.M., Sousa, M.G., Machado, M.A., Lima, A.M., Aguiar, M.E., Abé, K., Eulálio, M.C., Conceição, M.M., Silva, M.C. and Santos, M.G. (1982) Spread and Diversity of Human Populations in Bahia, Brazil. Human Biology, 54, 329-341.

[24] Pagliaro, H., Azevedo, M.M. and Santos, R.V. (2005) Demografia dos povos indígenas no Brasil. Fiocruz, 192. https://doi.org/10.7476/9788575412541

[25] Cecatti, J.G., Guerra, G.V.Q.L., Sousa, M.H. and Menezes, G.M.S. (2010) Aborto no Brasil: Um enfoque demográfico. Revista Brasileira de Ginecologia e Obstetrícia, 32, 105-111. https://doi.org/10.1590/S0100-72032010000300002

[26] Carvalho, T.S., Pellanda, L.C. and Doyle, P. (2018) Stillbirth Prevalence in Brazil: An Exploration of Regional Differences. The Journal of Pediatrics, 94, 200-206. https://doi.org/10.1016/j.jped.2017.05.006

[27] França, E.B., Lansky, S., Rego, M.A.S., Malta, D.C., França, J.S., Teixeira, R., Porto, D., Almeida, M.F., Souza, M.F.M., Szwarcwald, C.L., Mooney, M., Naghavi, M. and Vasconcelos, A.M.N. (2017) Leading Causes of Child Mortality in Brazil, in 1990 and 2015: Estimates from the Global Burden of Disease Study. The Revista Brasileira de Epidemiologia, 20, 46-60. https://doi.org/10.1590/1980-5497201700050005

[28] Diderichsen, F., Evans, T. and Whitehead, M. (2001) The Social Basis of Disparities in Health. In: Evans, T., Whitehead, M., Bhuiya, A., Diderichsen, F. and Wirth, M., Eds., Challenging Inequities in Health: From Ethics to Action, Oxford University Press, Oxford. https://doi.org/10.1093/acprof:oso/9780195137408.003.0002

[29] Pereira, S.A., Walsdchmidt, A.M. and Barbosa, A.A.L. (2012) Estudo De Sobrenomes Em Uma Comunidade Semi-Isolada Da Região Sudoeste Da Bahia. II Work. Genética, Biodiversidade e Conservação.

[30] Barbosa, A.A.L., Sousa, S.M.B., Abé-Sandes, K., Alonso,C.A., Schneider, V., Costa, D.C.C., Cavalli, I.J. and Azevêdo, E.E.S. (2006) Microsatellite Studies on an Isolated Population of African Descent in the Brazilian State of Bahia. Genetics and Molecular Biology, 29, 23-30. https://doi.org/10.1590/S1415-47572006000100004

[31] Freire-Maia, N. (1957) Inbreeding in Brazil. The American Journal of Human Genetics, 9, 284-298.

[32] Sandridge, A.L., Takeddin, J., Al-Kaabi, E. and Frances, Y. (2010) Consanguinity in Qatar: Knowledge, Attitude and Practice in a Population Born between 1946 and 1991. Journal of Biosocial Science, 42, 59-82. https://doi.org/10.1017/S002193200999023X

[33] Hamamy, H. (2012) Consanguineous Marriages Preconception Consultation in Primary Health Care Settings. Journal of Community Genetics, 3, 185-192. https://doi.org/10.1007/s12687-011-0072-y

[34] Soares, L.F., Lima, E.M., Silva, J.A., Fernandes, S.S., Silva, K.M.C., Lins, S.P., Damasceno, B.P. G.L., Verde, R.M.C.L. and Gonçalves, M.S. (2017) Prevalência de hemoglobinas variantes em comunidades quilombolas no estado do Piauí, Brasil. Ciência e Saúde Coletiva, 22, 3773-3780. https://doi.org/10.1590/1413-812320172211.04392016

[35] Santos, J.P. and Neto, M.G. (2013) Sociodemographic Aspects and Quality of Life of Patients with Sickle Cell Anemia. Revista Brasileira de Hematologia e Hemoterapia, 35, 242-245. https://doi.org/10.5581/1516-8484.20130093

[36] Simões, B.P., Pieroni, F., Barros, G.M.N., Machado, C.L., Cançado, R.D., Salvino, M.A., Ângulo, I. and Voltarelli, J.C. (2010) Brazilian Consensus Meeting on Stem Cell Transplantation: Hemoglobinopathies Committee. Revista Brasileira de Hematologia e Hemoterapia, 32, 46-53. 
https://doi.org/10.1590/S1516-84842010005000020

[37] Bhandiwad, A. and Gowda, S. (2015) Situs Inversus Totalis : A Case Report and Review. Journal of Medical Science and Clinical Research, 5, 7686-7688.

https://doi.org/10.18535/jmscr/v3i9.65

[38] Dahdouh, A., Taleb, M., Blecha, L. and Benyamina, A. (2016) Genetics and Psychotic Disorders: A Fresh Look at Consanguinity. European Journal of Medical Genetics, 59, 104-110. https://doi.org/10.1016/j.ejmg.2015.12.010

[39] Hamamy, H., Antonarakis, S.E., Cavalli-Sforza, L.L., Temtamy, S., Romeo, G., Kate, L.P., Bennett, R.L., Shaw, A., Megarbane, A., Van Duijn, C., Bathija, H., Fokstuen, S., Engel, E., Zlotogora, J., Dermitzakis, E., Bottani, A., Dahoun, S., Morris, M.A., Arsenault, S., Aglan, M.S., Ajaz, M., Alkalamchi, A., Alnaqeb, D., Alwasiyah, M.K., Anwer, N., Awwad, R., Bonnefin, M., Corry, P., Gwanmesia, L., Karbani, G.A., Mostafavi, M., Pippucci, T., Ranza-Boscardin, E., Reversade, B., Sharif, S.M., Teeuw, M.E. and Bittles, A.H. (2011) Consanguineous Marriages, Pearls and Perils: Geneva International Consanguinity Workshop Report. Genetics in Medicine, 13, 841-847. https://doi.org/10.1097/GIM.0b013e318217477f 